\title{
Microbial communities of apple orchard soils receiving long-term copper fungicides
}

\author{
Quan-Ying Wang \\ Northeast Institute of Geography and Agroecology \\ Chinese Academy of Sciences \\ Changchun, China \\ Dong-Mei Zhou \\ Institute of Soil Science \\ Chinese Academy of Sciences \\ Nanjing, China
}

\begin{abstract}
The aim of this study was to investigate the effect of long-term application of $\mathrm{Cu}$-based fungicides on soil microbial communities using profiling of phospholipid fatty acids (PLFAs). The results showed that the total PLFA, Gram-positive bacteria, Gram-negative bacteria, fungal PLFA contents, and fungi/bacteria ratio varied among the orchard soils with different planting-time. Stepwise regression analysis between PC1 and PC2 scores for PLFA data and soil properties showed that the change of PC2 was mainly due to the available soil $K(r=0.84, p<0.05)$, which suggested that soil fertilization could reduce the negative effects of $\mathrm{Cu}$ to the soil environment.
\end{abstract}

Index Terms-Apple orchard soil, copper fungicides, profiling of phospholipid fatty acids

\section{I . INTRODUCTION}

Pollution of agricultural soils by heavy metals from industrial and agricultural activities is a major environmental problem. Heavy metal pollution cannot only result in adverse effects on various parameters relating to plant quality and yield, but also could cause changes in the size, composition and activity of the soil microbial communities [1]. Phospholipid fatty acid (PLFA) analysis is commonly used to indicate community structure [2]. Phospholipid fatty acids are major constitutes of the membranes of all living cells, and different groups of microorganisms could be characterized by the changes of specific PLFA profiles in soil microbial composition [3].

Copper-based fungicides have been recognized for more than two centuries [4], and foliar application of these fungicides has led to a significant input of $\mathrm{Cu}$ to soil, through direct application, drift, or dripping of excess sprays from leaf surfaces. As fungicides are applied to control fungal diseases, they will also affect soil beneficial fungi and other soil organisms. Therefore, in many regions of the world there are increasing concerns that $\mathrm{Cu}$ may reach the concentrations in orchard soils toxic to soil organisms, microbial activities, enzyme activities, or even phytotoxicity [5]. However, limited studies have been done to study the changes of soil microbial community due to the long-term application of $\mathrm{Cu}$-based fungicides. In addition, quantifying the long-term responses of microbial populations to $\mathrm{Cu}$-based fungicides is important because of relatively large-scale of orchards in many countries.

The objective of this study was to evaluate the changes of soil microbial community using a set of complementary techniques that included PLFA profiling to evaluate changes in structural composition due to the long-term application of $\mathrm{Cu}$ fungicides in orchards.

\section{MATERIALS AND METHODS}

\section{A. Study sites and Experimental Design}

The research area is located at Rizhao City, the southeast of Shandong Province, China. About $16 \mathrm{~kg}$ Bordeaux mixture (the ratio of $\mathrm{CuSO}_{4}: \mathrm{CaO}: \mathrm{H}_{2} \mathrm{O}$ is $1: 2: 250$ ) per hare was applied to the orchards per year right from the beginning of the apple trees being planted.

The soil samples were collected from six spots in each orchard. The soil sub-samples were collected at a distance of 1 $\mathrm{m}$ from apple tree trunk at a depth of $0-20 \mathrm{~cm}$. An adjacent forest which had not received any artificial input of $\mathrm{Cu}$ (native soil) about $1 \mathrm{~km}$ away from the orchards was chosen to collect a reference soil. Part of each soil sample was air-dried at ambient temperature, the remaining soil was kept moist in the dark at 4 ${ }^{\circ} \mathrm{C}$ to determine PLFAs.

\section{B. Analytical Methods}

The soil samples were digested with $\mathrm{HF}-\mathrm{HNO}_{3}-\mathrm{HClO}_{4}$ for determination of total soil metal $(\mathrm{Cu}, \mathrm{Cd}, \mathrm{Cr}, \mathrm{Mn}, \mathrm{Ni}, \mathrm{Pb}$, and $\mathrm{Zn}$ ) concentrations by Inductively Coupled Plasma (ICP). Soil $\mathrm{pH}$ was measured by a $\mathrm{pH}$ meter with a ratio of 1:2.5 soil to water. Soil total organic carbon $\left(\mathrm{C}_{\text {org }}\right)$ was determined by oxidizing a soil solution with $\mathrm{K}_{2} \mathrm{Cr}_{2} \mathrm{O}_{7}$ and concentrated $\mathrm{H}_{2} \mathrm{SO}_{4}$ at $170-185^{\circ} \mathrm{C}$, and then titrating the solution with $\mathrm{FeSO}_{4}$. 
Available soil $\mathrm{N}, \mathrm{P}$, and $\mathrm{K}$ concentrations were determined according to [6], [7], and [8], respectively. Soil solution free $\mathrm{Cu}$ ions were determined using a $\mathrm{Cu}$ ion-selective electrode (Cu-ISE: Orion-94-29 vs Thermo Electron $\mathrm{Ag} / \mathrm{AgCl}$ Orion 90-02, Thermo Electron Corp.).

PLFAs were extracted from freeze-dried soil with chloroform/methanol/citrate buffer (0.15 mol/L, $\mathrm{pH} 4.0)$ 1:2:0.8 (v/v/v). Pooled supernatants (two repeated extractions) were split into two phases by the addition of chloroform and the above extracting buffer. The lipid-containing phase was transferred to burned glass tubes, dried under $\mathrm{N}_{2}$, dissolved in $600 \mathrm{ml}$ of chloroform, and transferred to a silica gel cartridge (500 mg, $3 \mathrm{ml}$; Supelco, Bellofonte, PA, USA). Following the elution of neutral lipids and glycolipids with $10 \mathrm{ml}$ chloroform and $10 \mathrm{ml}$ acetone, respectively, phospholipids were eluted with $8 \mathrm{ml}$ methanol and dried under $\mathrm{N}_{2}$. Methyl myristate fatty acid (19:0) was added as internal standard, and PLFAs were subsequently derivatized by mild-alkali methanolysis. The resulting fatty acid methyl esters were then separated and identified by Agilent $6890 \mathrm{~N}$ gas chromatography (Agilent, Wilmington, DE, USA) fitted with a MIDI Sherlock® microbial identification system (Version 4.5, MIDI, Newark, NJ, USA). Individual fatty acids were designated in terms of total number of carbon atoms: number of double bonds, followed by the position $(\omega)$ of the double bond from the methyl end of the molecule. The prefixes " $a$ " and " $i$ " indicate anteiso- and iso-branching, respectively, and " $10 \mathrm{Me}$ " describes a methyl group on the tenth carbon atom from the carboxyl end of the molecule, and "cy" represents a cyclopropane fatty acid. Gram-positive bacteria were identified by the PLFAs: i15:0, a15:0, i16:0, i17:0, a17:0 and 10Me17:0 and Gram-negative

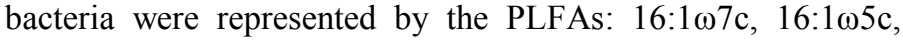
cy17:0, 18:1 $\omega 7 \mathrm{c}$ and cy19:0. The quantity of the fatty acid $18: 2 \omega 6,9 \mathrm{c}$ was used as an indicator of fungal biomass since it is suggested to be mainly of fungal origin in soil [10]. Ratios of $\mathrm{Gram}^{-} / \mathrm{Gram}^{+}$PLFA and fungi/bacteria PLFA were used as indicators for changes in the relative abundance of these microbial groups.

\section{Statistical analysis}

All statistical analyses were carried out with the program SPSS 16.0 for Windows. Simple correlation procedures were used to study the relationship between individual PLFA and the soil physicochemical properties. PLFAs were also analyzed initially by principal component analysis (PCA) to reduce the dimensionality. Statistical significance is accepted when the probability of the result assuming the null hypothesis (p) is less than 0.05 .

\section{RESULTS}

\section{A. Soil Physical and Chemical Properties}

Soil physicochemical properties were shown in TABLE I . No difference was found between the orchard soils and the control soil for soil $\mathrm{Cd}, \mathrm{Cr}, \mathrm{Mn}, \mathrm{Ni}, \mathrm{Pb}$, and $\mathrm{Zn}$ except soil $\mathrm{Cu}$. The soil $\mathrm{pH}$ ranged from 4.28 to 5.17 was generally acidic for both the fungicide treated and the reference soils. Soil $\mathrm{C}_{\mathrm{org}}$ varied from 5.29 to $6.22 \mathrm{~g} / \mathrm{kg}$, and the soil water holding capacity ranged from 25.2 to $31.6 \%$. The mean available soil $\mathrm{N}, \mathrm{P}$, and $\mathrm{K}$ varied considerably among soil samples in the orchards. The total $\mathrm{Cu}$ concentration in the reference soil was low $(12.5 \mathrm{mg} / \mathrm{kg})$, while the average concentration of soil $\mathrm{Cu}$ differed markedly with the orchard ages, being 21.8 (5 years), 17.8 (15 years), 41.9 (20 years), 103 (30 years), and $141 \mathrm{mg} / \mathrm{kg}$ (45 years), respectively. The mean soil solution free $\mathrm{Cu}^{2+}$ concentrations varied in the range of $3.13 \times 10^{-8}$ and $4.08 \times 10^{-6} \mathrm{~mol} \mathrm{~L}^{-1}$, being the lowest in the reference soil and highest in the orchard aged 45 years.

\section{B. Phospholipid Fatty Acid Profile}

The average total PLFA, Gram-positive bacteria,

TABLE I . MEAN SOIL PHYSICOCHEMICAL PROPERTIES FOR APPLE ORCHARD AND REFERENCE SOIL.

\begin{tabular}{lccccccc}
\hline $\begin{array}{l}\text { Soil } \\
\text { properties }\end{array}$ & $\mathbf{p H}$ & $\mathbf{C}_{\text {org }}$ & $\mathbf{A S P}$ & $\begin{array}{l}\mathbf{A S} \\
\mathbf{K}\end{array}$ & $\mathbf{A S ~ N}$ & $\mathbf{C u}$ & Free $\mathbf{C u}^{2+}$ \\
\hline Ref. & 4.68 & 5.45 & 38.8 & 49.0 & 13.1 & 12.5 & $3.13 \mathrm{E}^{-8}$ \\
5 years & 5.17 & 6.22 & 158 & 202 & 69.1 & 21.8 & $1.41 \mathrm{E}^{-7}$ \\
15 years & 4.65 & 6.02 & 256 & 242 & 148 & 17.8 & $7.81 \mathrm{E}^{-8}$ \\
20 years & 4.70 & 5.29 & 424 & 442 & 216 & 41.9 & $1.47 \mathrm{E}^{-6}$ \\
30 years & 4.28 & 6.14 & 379 & 355 & 260 & 103 & $2.97 \mathrm{E}^{-6}$ \\
45 years & 4.28 & 5.53 & 230 & 449 & 219 & 141 & $4.08 \mathrm{E}^{-6}$ \\
\hline
\end{tabular}

$\mathrm{C}_{\text {org }}$, total soil organic carbon $(\mathrm{g} / \mathrm{kg})$; ASP, available soil $\mathrm{P}, \mathrm{mg} / \mathrm{kg}$; ASK, available soil $\mathrm{K}, \mathrm{mg} / \mathrm{kg}$; ASN, available soil $\mathrm{N}, \mathrm{mg} / \mathrm{kg}$; $\mathrm{Cu}, \mathrm{mg} / \mathrm{kg}$; free $\mathrm{Cu}^{2+}$, $\mathrm{mol} / \mathrm{L}$.

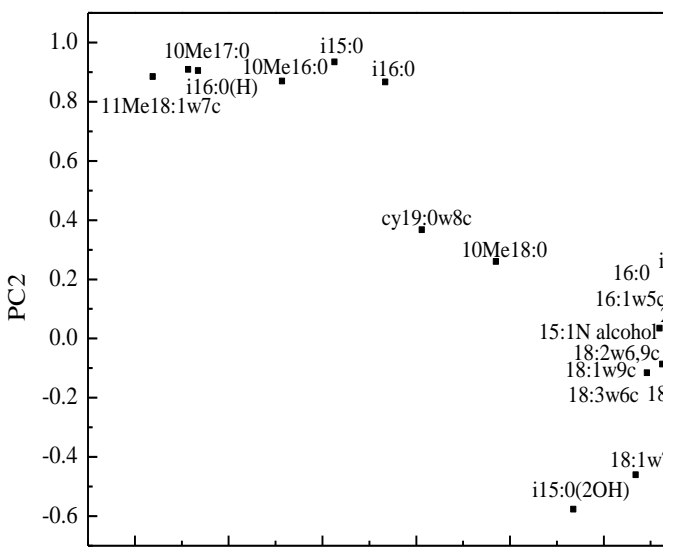

Fig. 1. Score plot of principal component analysis showing the separation of the study plots along PC1 and PC2 using PLFA data and the corresponding loading values for the PLFAs.

Gram-negative bacteria, and total fungal PLFA contents for the sampling sites were shown in TABLE II. The average total PLFA content in the reference soil was $23.7 \mathrm{nmol} / \mathrm{g}$ dry soil, while the values for the orchard soils were 19.3 (5 years), 27.3 
(15 years), 26.3 (20 years), 39.6 (30 years), and 23.7 (45 years) $\mathrm{nmol} / \mathrm{g}$ dry soil, respectively. The ratios of fungi/bacteria PLFA and $\mathrm{Gram}^{-} / \mathrm{Gram}^{+}$PLFA varied from 0.04 to 0.11 and 0.51 to 0.92, respectively. No significant relationship was found between the total PLFA, Gram-positive bacteria, Gram-negative bacteria, total fungal PLFA contents, or ratio of fungi/bacteria PLFA and the soil physicochemical properties. However, the ratio of $\mathrm{Gram}^{-} / \mathrm{Gram}^{+}$was significantly related to soil total $\mathrm{Cu}$ concentration $(\mathrm{r}=0.88, \mathrm{p}<0.05)$, soil solution free $\mathrm{Cu}^{2+}(\mathrm{r}=$ $0.84, \mathrm{p}<0.05)$, available soil $\mathrm{N}(\mathrm{r}=0.97, \mathrm{p}<0.05)$, and available soil $\mathrm{K}(\mathrm{r}=0.94, \mathrm{p}<0.05)$, respectively. The data of the 24 most common PLFAs were subjected to a principal principal component (PC1) explained about $61.2 \%$ of the variation in the data set, while the second, PC2, explained $24.0 \%$. Stepwise regression analysis

TABLE II . MEAN SOIL INDICATORS OF PLFAS FOR APPLE ORCHARD AND REFERENCE SOILS.

\begin{tabular}{llllll}
\hline $\begin{array}{l}\text { Indicators of } \\
\text { PLFAs }\end{array}$ & Gram $^{+}$ & Gram $^{-}$ & Fungal & $\begin{array}{l}\text { fungi/ } \\
\text { bacteria }\end{array}$ & $\begin{array}{l}\text { Gram }^{-} \\
\text {/Gram }^{+}\end{array}$ \\
\hline Ref. & 5.96 & 3.02 & 0.41 & 0.04 & 0.51 \\
5 years & 4.21 & 2.80 & 0.65 & 0.08 & 0.66 \\
15 years & 5.59 & 3.86 & 0.97 & 0.09 & 0.69 \\
20 years & 5.19 & 4.35 & 0.94 & 0.08 & 0.84 \\
30 years & 7.06 & 6.55 & 1.66 & 0.11 & 0.92 \\
45 years & 4.76 & 4.38 & 0.63 & 0.06 & 0.92 \\
\hline
\end{tabular}

$\mathrm{Gram}^{+}$, gram-positive PLFA, nmol/g dry soil; Gram-, gram-negative PLFA, nmol/g dry soil; Fungal PLFA, nmol/g dry soil.

between PC1 and PC2 scores for PLFA data and soil properties showed that none of metal variables or the other soil physicochemical properties measured was included in the regression equation as independent variables for $\mathrm{PC} 1$, while the change of PC2 was mainly due to the available soil $\mathrm{K}(\mathrm{r}=0.84$, $\mathrm{p}<0.05)$. The individual PLFAs mostly responsible for the changes along PC2 were i15:0, i16:0, i16:0(H), 10Me16:0,

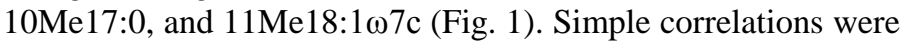
done between fatty acid concentrations and soil basic physicochemical characteristics. It is interesting to note that two of the fatty acids (i15:0(2OH) and $11 \mathrm{Me} 18: 1 \omega 7 \mathrm{c})$ were significantly related to the soil free $\mathrm{Cu}^{2+}(\mathrm{r}=0.85$ and $-0.86, \mathrm{p}<$ 0.05 , respectively).

\section{DISCUSSION}

Studies about soil microorganism in orchards are mainly focusing on the soil microbial biomass carbon, $\mathrm{C}$ mineralization, and specific respiration rate. However, such measurements only consider the microbial community as a whole, and questions remain as to how metal contamination affects specific populations within soil microbial communities [9]. Phospholipid fatty acid profiles are frequently used to distinguish the microbial community structure between different sites or treatments [10], and this method has been used to assess the microbial community characteristics in soil samples obtained from orchards differing in age, and from a neighbouring forest.

In contaminated soils, a population shift in favor of resistant microorganisms occurs due to the elimination of sensitive organisms, and such population shifts can lead to changes in phospholipid fatty acid patterns of the soil. Changes in microbial community structure, as determined by changes in PLFA profiles, have been reported in $\mathrm{Cu}-, \mathrm{Ni}-, \mathrm{Cr}-$, and Zn-contaminated soils $[11,12]$. Therefore, the PLFA profiles were also used to investigate the effect of $\mathrm{Cu}$-based fungicides on soil microbial community structure in this study. The mean total $\mathrm{Cu}$ and free $\mathrm{Cu}^{2+}$ concentrations of orchard soils had a tendency to increase with the increase of orchard years that the $\mathrm{Cu}$-containing fungicides (Bordeaux mixture) were used. In theory, the increasing $\mathrm{Cu}$ load might have imposed selective pressure and osmotic stress on soil microbial community. However, no significant relationship was found between the soil total PLFA, Gram-positive bacteria, Gram-negative bacteria, total fungal PLFA contents, or ratio of fungi/bacteria PLFA and soil total $\mathrm{Cu}$ concentration or soil solution free $\mathrm{Cu}^{2+}$ in this study. Instead, when the principal component analysis was used, we found that the changes of PLFAs in this study were mainly due to available soil $\mathrm{K}$, and the ratio of $\mathrm{Gram}^{-} / \mathrm{Gram}^{+}$was also significantly related to available soil $\mathrm{N}$ and available soil $\mathrm{K}$. Some studies have already shown that soil heavy metals often adversely affected microorganisms, but changes in abundances of signature PLFAs did not consistently change with heavy metal contents, and this may be because even though the community structure was different, its diversity was not, or it could represent some problems using fatty acid profiles to measure the diversity. Bååth et al. [13] suggested that the disadvantage of PLFA analysis as a monitoring tool in studying environmental pollution is that the PLFA pattern is often affected by other environmental factors such as soil moisture, $\mathrm{pH}$ and temperature, etc, which was also convinced by this study. The soil fertilization is possibilities for reducing the negative effects of heavy metals in the environment since nutrients would improve the low nutritional status of the polluted soil [11]. Another reason for the unaffected general PLFA pattern might be the very low levels of heavy metals in the present study, lower than e.g. the levels where the first signs of changed PLFA patterns were found, and the PLFA pattern would be affected only by considerably higher levels of metals. In this study, we have found that increasing $\mathrm{Cu}$ loading in the orchards can cause the changes of ratio of $\mathrm{Gram}^{-} / \mathrm{Gram}^{+}$PLFA

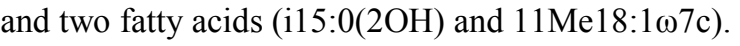

\section{CONCLUSIONS}

The community-level profiling technique (PLFA profiling) was used to evaluate the changes in soil microbial structural composition due to long-term application of $\mathrm{Cu}$ fungicides in the orchards. The structure of microbial communities at the sampling sites have not been significantly affected by the $\mathrm{Cu}$ 
inputs. Meanwhile, the different fertilizer practices have an impact on the community structure of specific microbial groups. However, although the changes in the microbial variables of the orchard soils were relatively small, more attention should be paid due to continuous application of $\mathrm{Cu}$ fungicides.

\section{ACKNOWLEDGMENT}

This work is supported by the National Natural Science Foundation of China (No. 41101305).

\section{REFERENCES}

[1] K. E.Giller, E. Witter, S. P. McGrath, "Toxicity of heavy metals to microorganisms and microbial processes in agricultural soils: a review," Soil Biol. Biochem., vol. 30, pp. 1389-1414, 1998.

[2] E. Bååth, M. Díaz-Raviña, L. R. Bakken, "Microbial biomass, community structure and metal tolerance of a naturally $\mathrm{Pb}$-enriched forest soil," Microb. Ecol., Vol. 50, pp. 496-505, 2005.

[3] E. Puglisi, M. Nicelli, E. Capri, M Trevisan, A. M. Attilio, A. A. M. Del Re, "A soil alteration index based on phospholipid fatty acids," Chemosphere, vol. 61, pp. 1548-1557, 2005.

[4] U. Pietrzak, D. C. McPhail, "Copper accumulation, distribution and fractionation in vineyard soils of Victoria, Australia," Geoderma, Vol. 122, pp. 151-166, 2004.

[5] W. Q. Li, M. Zhang, H. R. Shu, "Distribution and fractionation of copper in soils of apple orchards," Environ. Sci. Pollut. R., Vol. 12, pp. $168-172,2005$.

[6] D. W. Nelson, J. M. Bremner, "Preservation of soil samples for inorganic nitrogen analyses,” Agronmy J., vol. 64, pp. 196-199, 1972.

[7] R. H. Bray, L. T. Kurtz, "Determination of total, organic and available forms of P in soils," Soil Sci., Vol. 59, pp. 39-45, 1945.

[8] J. B. Jones, "Soil testing in the United States," Communications in Soil Science and Plant Analysis, vol. 4, pp. 307-322, 1973.

[9] P. A. Olsson, "Signature fatty acids provide tools for determination of the distribution and interactions of mycorrhizal fungi in soil," FEMS Microbiol. Ecol., vol. 29, pp. 303-310, 1999.

[10] J. J. Kelly, M. M. Häggblom, R. L. Tate, "Effects of heavy metal contamination and remediation on soil microbial communities in the vicinity of a zinc smelter as indicated by analysis of microbial community phospholipid fatty acid profiles," Biol. Fert. Soil, Vol. 38, pp. 65-71, 2003.

[11] T. Pennanen, "Microbial communities in boreal coniferous forest humus exposed to heavy metals and changes in soil $\mathrm{pH}-$ a summary of the use of phospholipids fatty acids, Biolog® and 3H-thymidine incorporation methods in field studies," Geoderma, vol. 100, pp. 91-126, 2001.

[12] B. Frey, M. Stemmer, F. Widmer, J. Luster, C. Sperisen, "Microbial activity and community structure of a soil after heavy metal contamination in a model forest ecosystem," Soil Biol. Biochem., vol. 38, pp. 1745-1756, 2006.

[13] E. Bååth, Å. Frostegård, M. Díaz-Raviña, A. Tunlid, "Microbial community-based measurements to estimate heavy metal effects in soil: the use of phospholipid fatty acid patterns and bacterial community tolerance," Ambio, vol. 27, pp. 58-61, 1998. 